\title{
REPORTS AND PAMPHLETS
}

Prisons in a State-Annual Report of the Howard League for Penal Reform 1976/77

The year 1977 was a landmark year for the Howard League for Penal Reform. It was the bicentenary of John Howard's book The State of the Prisons, and the League marked the occasion by, among other things, an international conference at Canterbury and the publication of an extended Annual Report. The report should be compulsory reading for any sensitive citizen, as it sets out for us some of the issues involved in locking away as prisoners some 75 persons per 100,000 of our population. It is encouraging to note that we are only 27 th in the league table of nations who will give figures, being soundly beaten by such freedom-loving countries as Israel, with $137 / 100,000$, the USA with $189 / 100,000$, and by a breathtaking $44^{1} / 100,000$ in South Africa. It is discouraging, however, to see how far in front of some other European countries we are, e.g. the Netherlands who lock up only $21 / 100,000$ and Spain with 40/100,000. Psychiatrists may wonder where the Soviet Union would appear in this analysis if it dared to give us accurate figures.

A Howard League solution is proposed to the long-running debate on whether offenders should be punished or rehabilitated. The answer, we are told, is to require offenders to do something constructive to make up for the harm they have caused. The League proposes that the basic principle should be reparation. 'In some cases, personal restitution is possible. Otherwise the community should take over assistance to the victim, and the offender should make reparation to the community. If he is socially disadvantaged he can also make amends by making use of education, training, counselling, therapy, or other help which is offered. Only in the most serious cases, or when a person was totally uncooperative, would the work have to be done in prison.' No taxpayer could argue with such a low-cost scheme, but the idea that the 'community', presumably Local Authority social workers, will care for the victims of crime will bring a wry smile to the lips of medical practitioners.

The big surprise about this report from the College member's point of view is the small amount of attention paid to psychiatry. It is difficult to know whether this is to be welcomed or regretted. It could be that the League has no unrealistic notions about the powers and virtues of psychiatry in criminology. On the other hand, with the disregarded Butler Report collecting dust, the impotence of DHSS to persuade psychiatrists to provide services for offenders, regular comments about the depth of the forensic psychiatry crisis appearing in the newspapers, and the number of mentally sick people being sent to prison going up annually, it is surprising that the League is not yet more alarmed. They do, however, pass on a prisoner's relatives' complaint that Grendon uses only 189 of its theoretical 300 places, and they do promise us the published proceedings of an interesting conference on 'Medical Services for Offenders' held at the King's Fund Centre on 22 October 1976. This report, which seems unduly delayed, should give the substance of a valuable dialogue between NHS psychiatrists and senior prison doctors and could make a contribution to our own College's deliberations about forensic problems.

Other League developments which may be of interest to psychiatrists are the establishment of a committee to pursue the problems of dealing with juveniles, and the setting up of a working party under the chairmanship of Mrs Floud to examine the problems of the dangerous offender.

The Report is obtainable from the League office, 125 Kennington Park Road, London SE I I, price 50p.

JoHn GunN

Day Services for Mentally Handicapped Adults. National Development Group for the Mentally Handicapped. Pamphlet No. 5, July 1977.

The emphasis throughout this pamphlet is on the educational aspects of the work of the day services, and it is suggested that adult training centres, while still remaining with Social Services Departments, should in future be known as Social Education Centres and those attending known as students.

A centre at the upper end of the 50-150 places recommended in DHSS Local Authority Building Note No. 5 is suggested, sited so as to enable students and staff to form part of the local community.

The centre is envisaged as consisting of four sections: Admission and Assessment Section (AAS), Development and Activity Section (DAS), Special Care Section (SCS) and Advanced Work Section (AWS), but it is emphasized that flexibility is the essential ingredient if the structure is to work effectively, and that no placement or programme for a mentally handicapped person within the centre should be regarded as permanent. Everyone should first go through the Admission and Assessment Section, whatever their age or background and 
irrespective of multi-disciplinary assessment elsewhere. Emphasis also is placed on communication between the centre and all other statutory and voluntary services providing care for the mentally handicapped. Attendance at the centre by those who are resident in Health Service or Local Authority accommodation is envisaged, as is the attendance of students from the centre at educational establishments elsewhere.

The Development and Activity Section is regarded as the main section of the centre, but it is stressed that occupation for occupation's sake is of little value; it should be geared towards developing the abilities of the student rather than merely keeping him busy or fulfilling a contract.

The Advanced Work Section should provide a more realistic pre-work experience with increased demands and expectations than in any other part of the centre, but should retain the overall educative objective of the whole centre. Work contracts within the section should be chosen to represent the type of activity in which the student who has gained outside employment is likely to be involved. The programme should include discussion of national insurance, problems of income tax, trade union affairs, etc.

The criteria for attendance in the Special Care Section are defined as, in addition to mental handicap, other incapacities rendering a person unable to benefit or preventing others from benefiting from the usual range of education and training programmes in the centre. It is stressed that the profoundly handicapped have as much need for systematic assessment and careful planning as any other students, and that the Special Care Section should not be regarded as an isolated haven of care segregated from the rest of the centre; and its activities, too, should be an integral part of the centre, with the task of meeting the special needs of some of its students. Some of the people in the Special Care Section should spend a proportion of their time in some other Section. A ratio of I staff member to 3 people is recommended as the minimum level compatible with the training functions of the Special Care Section and staff-tostudent ratios are recommended also for each of the other Sections within the centre.

It is envisaged that the officer in charge should be a Manager, with overall responsibility for the day to day decision making being shared by a Management Team consisting of the head of each section.

The importance of ensuring smooth transfer of students from school to the centre is stressed and of keeping accurate written records of their initial assessment and progress. It is recognized that the conventional long holidays enjoyed by schools, colleges and other educational establishments are not appropriate for the Social Education Centre despite its educational role, and the hope is expressed that the centre would not be closed for more than two weeks at any one time. The importance of adequate preparation for work outside of the centre is also stressed.

Each member of the Management Team should hold the appropriate qualifications for working in a Day Centre for mentally handicapped adults and the need for a number of new specialist roles within the special education centre such as counsellor, schools liaison officer and peripatetic instructor is recognized. It is suggested there should also be a local advisory or consultative group with overall responsibility for reviewing progress and advising on the development of the centre, representing sources of advice and expertise in the local community and including one or more parents.

There are chapters on payments and incentives, leisure and recreation, counselling for students and families and on using community resources, all of which contain very valuable guidance.

This is an excellent document, more deserving of the designation 'Textbook' than 'Pamphlet'. There is very little to criticize generally, apart from a tendency in later sections to repeat recommendations made earlier. Most of the the text is clearly written and unambiguous, with a refreshing absence of jargon. But is it really true that all mentally handicapped school leavers possess levels of ability and attainments no higher than those of normal children entering the school system at the age of 5 , as paragraph 22 seems to imply? And what is 'an option focused on life/ stage' referred to in paragraph 115 ? Having made the clear and commendable statement in paragraph 96 that the Manager of the Centre has overall responsibility for the running of the Centre it is unfortunate that the Pamphlet should prescribe in paragraph 113 the currently fashionable anodyne of 'direct responsibility shared between the Manager and the Management Team'.

In his foreword, Professor Peter Mittler, Chairman of the National Development Group, expresses the hope that the applicability of its recommendations to hospital residential settings will be considered by the staff concerned, and this hope can be warmly endorsed.

W. A. Heaton-Ward 